Tyshchenko Yuliia, $\mathrm{PhD}$ (Law Sciences), Associate Professor, Kyiv National University of Trade and Economics, 19, Kyoto str., Kyiv, 02156, Ukraine

ORCID: 0000-0002-3799-4227

Researcher ID: M-4147-2016

\title{
CONSTITUTIONAL REGULATION OF ENSURING THE RIGHTS OF CONSUMERS OF UKRAINE AND FOREIGN COUNTRIES: COMPARATIVE LEGAL ANALYSIS
}

The article analyzes the legal regulation of consumer protection in the Constitution of Ukraine and formulates suggestions for improving the current version of this legislative act. A comparative legal analysis of the provisions of the constitutions of foreign countries on the legal provision of consumer rights and taking into account their positive experience in this field was also carried out.

Keywords: consumer rights, constitution, constitutional provision of consumer rights.

Тищенко Юлія. Конституційне регулювання забезпечення прав споживачів в Украӥні та інших державах: порівняльний аналіз.

У статті здійснено аналіз правового регулювання забезпечення прав споживачів в Конституції Украӥни та сформульовані пропозиції щодо вдосконалення чинної редакиії иьього законодавчого акту. Також проведений порівняльноправовий аналіз положень конституцій зарубіжних країн щодо правового забезпечення прав споживачів та врахування їх позитивного досвіду в цій сфері.

Ключові слова: права споживачів, конституиія, конститучійне забезпечення прав споживачів.

Relevance of the research topic. The problem of ensuring consumer rights has existed since the inception of market social relations as a matter of finding and achieving a balance, harmonizing the various interests of individuals who sell goods and provide services, and those who consume them. Therefore, an integral part of a market economy is the creation of an institutional-legal mechanism for ensuring consumer rights.

Formulation of the problem. The leading role in creating this mechanism is played by the provisions of the Constitution, which enshrine the fundamental principles of building legal regulation of all public relations, including consumer 
rights. Therefore, studies of constitutional norms, both in Ukraine and in foreign countries, are of great importance for determining directions for improving national legislation in this area.

Analysis of recent research and publications. An analysis of the main provisions of the legislation on ensuring the rights of consumers was carried out by Horblyans'ky V.Ya. (Horblyans'ky, 2019), Hryshko U.P. (Hryshko, 2017), Il'chenko H.O. (Il'chenko, 2017), Kotsovs'ka O.L. (Kotsovs'ka, 2014), Krehul Yu.I. (Krehul, 2018), Yanovyts'ka H.B. (Yanovyts'ka, 2018) and others. But these scientists studied this problem from the standpoint of civil, economic and administrative law.

Presenting main material. The Constitution of Ukraine was adopted on June 28, 1996 and consolidated the foundations of state policy in various areas of public life, including the provision of consumer rights (Konstytutsiya Ukrayiny, 1996). So, according to the fourth part of Article 42 of the Constitution of Ukraine, the state protects the rights of consumers, monitors the quality and safety of products and all types of services and works, promotes the activities of consumer organizations. According to the second part of Article 50 of the Constitution of Ukraine, everyone is guaranteed the right of free access to information on the quality of food products and household items, as well as the right to disseminate it. Such information cannot be classified by anyone.

Emphasizing the importance of the above constitutional provisions to ensure the rights of consumers, at the same time, we believe that they require some improvement. This, in our opinion, concerns the clarification of terminology, the expansion of the right of everyone to freely access information on the quality of food products and household items, the consolidation of provisions to ensure consumer rights in a separate article.

This applies to the fourth part of Article 42 of the Constitution of Ukraine, according to which the state protects the rights of consumers, monitors the quality and safety of products and all types of services and works, and promotes the activities of consumer organizations. A similar provision was contained in the third part of Article 47 of the draft Law of Ukraine «On Amendments to the Constitution of Ukraine» (reg. No. 4290 dated 03/31/2009) submitted to the Parliament by the President of Ukraine (on October 22, 2009 this draft was canceled by the Verkhovna Rada of Ukraine) (Proekt Zakonu Ukrayiny «Pro vnesennya zmin...», 2009).

These provisions do not use the term «goods». At the same time, in international law, products, services and work are understood as varieties of goods. In this regard, we believe it is correct in the course of further implementation of the constitutional reform to amend the fourth part of Article 42 of the Constitution of Ukraine, so that the state exercises control over the quality and safety of goods (products, services, works).

We suggest making similar changes to paragraph 1 of Article 1 of the Law of Ukraine «On the Protection of Consumer Rights» (Zakon Ukrayiny «Pro zakhyst prav spozhyvachiv», 1991) where the term «product» is defined as any product (product), 
work or service that is manufactured, performed or provided to meet public needs. In this Law, services and work are understood as varieties of products, not goods.

The importance of improving the constitutional provisions on ensuring consumer rights lies in the fact that the constitution is the legal basis for current legislation.

During the improvement of constitutional requirements in this area, it seems useful to study and take into account the European experience of constitutional regulation of consumer protection.

The national program of adaptation of the legislation of Ukraine to the legislation of the European Union, approved by the Law of Ukraine of March 18, 2004, consumer protection was identified as one of the priority areas in which the adaptation of the legislation of Ukraine was carried out (Zakon Ukrayiny «Pro Zahal'noderzhavnu prohramu adaptatsiyi...», 2004). Many provisions on consumer protection have found their place in the Association Agreement between Ukraine and the European Union of March 21, 2014 (Uhoda pro asotsiatsiyu mizh Ukrayinoyu..., 2014).

At the same time, it should be noted that European Union directives establish general requirements that individual member states must comply with, and not how their national laws should be organized. Therefore, there are certain differences in the consumer legislation of individual states, including their basic laws.

The analysis showed that the constitutions of some countries of Western Europe contain norms to ensure consumer rights.

The Constitution of the Portuguese Republic of April 2, 1976 contains article 60 «Consumer Rights», according to which consumers have the right to the quality of goods and services that they consume, to receive education and information, to health care, to safety and protection of their economic interests, as well as to compensation damage. Advertising is regulated by law, while hidden or knowingly false advertising is prohibited. Consumer associations and consumer cooperatives have the right under the law to support from the state to be heard on issues related to consumer protection, while they recognize the right to participate in the process to protect their members or to protect collective interests or interests an indefinitely wide circle of persons (Konstytutsiya Respubliky Portuhaliya, 1976).

It should be said that in the Portuguese Constitution consumer rights are enshrined in a separate article. This eliminates the need to claim their inferiority, as is the case when they are mentioned in articles on other rights.

Spain and Norway are also states whose constitutions contain rules on consumer rights.

According to article 51 of the Constitution of Spain of December 27, 1978, the authorities guarantee the protection of consumers and users, providing effective means of their safety, health, as well as their legitimate economic interests. Authorities promote the dissemination of information among consumers and users, as well as their education, encourage their organization and the exercise of their right to contact the authorities on the conditions provided by law (Konstytutsiya Ispaniyi, 1978). 
The above provisions deserve support that they are not talking about consumer access to information, but about its dissemination, as well as their education.

Paragraph 110c of the Constitution of the Norwegian Kingdom of May 17, 1814 states that everyone has the right to protect natural food products and their diversity (Konstytutsiya Norvez'koho Korolivstva, 1814).

Among the states - «young» members of the European Union, in the context of constitutional regulation of consumer protection, it is worth noting Poland. The Constitution of the Republic of Poland of April 2, 1997 devotes a separate article 76 to the problem of consumer rights, according to which the public authority of Poland protects consumers, users and employers from actions that threaten their health, privacy and security, as well as from unfair market practices. The scope of this protection is determined by law (Konstytutsiya Pol's'koyi Respubliky, 2018, p. 32).

Of particular interest is the fact that the Constitution of the Republic of Poland, next to consumers, recalls users and employers as independent, distinct entities from consumers. In our opinion, this is unacceptable for Ukraine, since the legislative definition of the concept of «consumer» in paragraph 22 of Article 1 of the Law of Ukraine «On Protection of Consumer Rights» covers the concepts of «user» and «employer».

According to the Constitution of the Republic of Bulgaria of July 12, 1991 (part two of Article 19), the law creates and guarantees all citizens and legal entities the same legal conditions for economic activity, as well as prevents the abuse of monopolism, unfair competition and protects the consumer (Konstytutsiya Respubliky Bolhariya, 1991).

Article 46 of the Constitution of the Republic of Lithuania of October 25, 1992 proclaims the existence of state protection of consumer interests (Konstytutsiya Lytovs'koyi Respubliky, 1992).

As for the post-Soviet states, far from all of them paid attention to the constitutional regulation of consumer rights. Analyzing the basic laws of these countries, we find a direct mention of consumers only in the constitutions of Georgia and the Republic of Uzbekistan.

According to article 30 of the Georgian Constitution of August 24, 1995, consumer rights are protected by law (Konstytutsiya Hruziyi, 1995).

In the first part of Article 53 of the Constitution of the Republic of Uzbekistan dated December 8, 1992, a state guarantee of freedom of economic activity, business and labor is fixed, taking into account the priority of consumer rights (Konstytutsiya Respubliky Uzbekystan, 1992).

Such a state guarantee of human rights as the right of access to information on the state of the environment and on products, then the universal declaration of the right to information is found in almost every constitution of the CIS states and the «new» members of the European Union.

Conclusion. It can be concluded that the constitutions of most European countries do not contain norms that would directly regulate the provision of consumer 
rights. Only a few constitutions use the term «consumer» and it is a question of the state protecting its rights. In most European constitutions we find only general norms that guarantee the rights and freedoms of human and citizen, and which, through doctrinal interpretation, can be extended to consumer rights.

In this context, the presence in the Constitution of Ukraine of provisions aimed at ensuring the rights of consumers indicates the progressivity of our Constitution.

At the same time, some constitutional provisions need to be improved. Taking into account the positive experience of the constitutional regulation of ensuring the rights of consumers of some European states, as mentioned above, will contribute to the effectiveness of constitutional legislation in this area.

\section{REFERENCES}

1. Horblyans'kyy V.YA. Zakhyst prav spozhyvachiv za dohovorom pro nadannya posluh [Consumer protection under the service agreement] : avtoref. dys.... kand. yuryd. nauk : 12.00.03 / Horblyans'kyy Volodymyr Yaroslavovych ; Navch.nauk. yuryd. in-t DVNZ «Prykarpat. nats. un-t im. Vasylya Stefanyka». IvanoFrankivs'k, 2019. 20 s. [in Ukrainian].

2. Hryshko U.P. Zakhyst prav spozhyvachiv transportnykh posluh [Protection of the rights of consumers of transport services] : avtoref. dys.... kand. yuryd. nauk : 12.00.03 / Hryshko Ulyana Petrivna ; Derzh. VNZ «Prykarpat. nats. un-t im. Vasylya Stefanyka», Navch.-nauk. yuryd. in-t. Ivano-Frankivs'k, 2017. 19 s. [in Ukrainian].

3. Il'chenko H.O. Zakhyst prav spozhyvachiv strakhovykh posluh [Protecting the rights of consumers of insurance services] : monohrafiya / H. O. Il'chenko. Kyyiv : Kyyiv. nats. torh.-ekon. un-t, 2017. 183 s. [in Ukrainian].

4. Konstytutsiya Hruziyi vid 24 serpnya 1995 roku [The Georgian Constitution]. Retrieved from https://www.refworld.org/cgi-bin/texis/vtx/rwmain/ opendocpdf.pdf [in Ukrainian].

5. Konstytutsiya Ispaniyi vid 27 hrudnya 1978 roku [Constitution of Spain]. Retrieved from https://worldconstitutions.ru/?p=149 [in Ukrainian].

6. Konstytutsiya Lytovs'koyi Respubliky vid 25 zhovtnya 1992 roku [Constitution of the Republic of Lithuania]. Retrieved from https://legalns.com/ download/books/cons/bulgaria.pdf. [in Ukrainian].

7. Konstytutsiya Norvez'koho Korolivstva vid 17 travnya 1814 roku [Constitution of the Kingdom of Norway]. Retrieved from http://nbuviap.gov.ua/asambleya/ constitutions.php [in Ukrainian].

8. Konstytutsiya Pol's'koyi Respubliky (z peredmovoyu Volodymyra Shapovala) [Constitution of the Polish Republic (with a preface by Vladimir Shapoval)] / V.M. Shapoval. K.: Moskalenko O.M., 2018. 82 s., s. 32. [in Ukrainian].

9. Konstytutsiya Respubliky Bolhariya vid 12 lypnya 1991 roku [Constitution of the Republic of Bulgaria]. Retrieved from https://legalns.com/download/books/ cons/bulgaria.pdf [in Ukrainian]. 
10. Konstytutsiya Respubliky Portuhaliya vid 2 kvitnya 1976 roku [Constitution of the Republic of Portugal]. Retrieved from http://www.concourt.am/armenian/legal_ resources/world_constitutions/constit/portugal/portug-r.htm [in Ukrainian].

11. Konstytutsiya Respubliky Uzbekystan vid 8 hrudnya 1992 roku [Constitution of the Republic of Uzbekistan]. Konstytutsiyi novykh derzhav Yevropy ta Aziyi / Uporyad. S. Holovatyy. K. : Ukr. Pravn. Fundatsiya ; Pravo, 1996. 544 s. [in Ukrainian].

12. Konstytutsiya Ukrayiny № 254k/96-VR vid 28.06.1996 roku [Constitution of Ukraine]. Vidomosti Verkhovnoyi Rady Ukrayiny - Bulletin of the Verkhovna Rada of Ukraine. 1996. № 30. St. 141. [in Ukrainian].

13. Kotsovs'ka O.L. Administratyvno-pravovi zasoby okhorony prav spozhyvachiv [Administrative and legal remedies for consumer protection] : avtoref. dys.... kand. yuryd. nauk : 12.00.07 / Kotsovs'ka Oksana Lyubomyrivna ; NAN Ukrayiny, In-t derzhavy i prava im. V. M. Korets'koho. Kyyiv, 2014. 20 s. [in Ukrainian].

14. Krehul YU.I. Zakhyst prav spozhyvachiv finansovykh posluh [Protecting the rights of consumers of financial services] : monohrafiya / YU. I. Krehul, O. YU. Radchenko. Kyyiv : Kyyiv. nats. torh.-ekon. un-t, 2018. 263 s. [in Ukrainian].

15. Proekt Zakonu Ukrayiny «Pro vnesennya zmin do Konstytutsiyi Ukrayiny» : (reyestr. № 4290 vid 31.03.2009) [Draft Law of Ukraine «On Amendments to the Constitution of Ukraine»]. Retrieved from http://w1.c1.rada.gov.ua/pls/zweb_n/ webproc4_1?id=\&pf3511=34882. [in Ukrainian].

16. Uhoda pro asotsiatsiyu mizh Ukrayinoyu, $\mathrm{z}$ odniyeyi storony, ta Yevropeys'kym Soyuzom, Yevropeys'kym spivtovarystvom $z$ atomnoyi enerhiyi i yikhnimy derzhavamy-chlenamy, z inshoyi storony [Association Agreement between Ukraine, of the one part, and the European Union, the European Atomic Energy Community, and their Member States, of the other part]. Ofitsiynyy visnyk Ukrayiny Official Bulletin of Ukraine. 2014 r., № 75, tom 1, stor. 83, stattya 2125. [in Ukrainian].

17. Yanovyts'ka, H. B. Tsyvil'no-pravovi zasoby zakhystu prav spozhyvachiv v Ukrayini [Civil legal remedies for consumer rights protection in Ukraine] : monohrafiya / H. B. Yanovyts'ka. L'viv : Rastr-7, 2018. 400 s. [in Ukrainian].

18. Zakon Ukrayiny «Pro Zahal'noderzhavnu prohramu adaptatsiyi zakonodavstva Ukrayiny do zakonodavstva Yevropeys'koho Soyuzu» № 1629-XV vid 18.03.2004 r. [Law of Ukraine «On the National Program of Adaptation of the Legislation of Ukraine to the Legislation of the European Union»]. Vidomosti Verkhovnoyi Rady Ukrayiny - Bulletin of the Verkhovna Rada of Ukraine. 2004. № 29. St. 367. [in Ukrainian].

19. Zakon Ukrayiny «Pro zakhyst prav spozhyvachiv» № 1023-KHII vid 12.05.1991 r. [Law of Ukraine «Consumer Protection»]. Vidomosti Verkhovnoyi Rady URSR - Bulletin of the Supreme Soviet of the USSR. 1991. № 30. St. 379. [in Ukrainian]. 